\title{
EFFECTS OF NOMOPHOBIA AND MOBILE PHONE USE WITH EYE STRAIN IN UNIVERSITY STUDENTS
}

\author{
Firman Firdauz Saputra ${ }^{1}$, Zufra Inayah ${ }^{2}$ \\ Program Studi D3 Farmasi, Akademi Kesehatan Farmasi, Sumenep ${ }^{1}$ \\ Fakultas Ilmu Kesehatan, Universitas Muhammadiyah Gresik, Gresik ${ }^{2}$ \\ Firman.firdauz@akademikesehatansumenep.ac.id ${ }^{1}$, Zufra@umg.ac.id ${ }^{2}$
}

\begin{abstract}
Increased features and functions cause negative effects such as nomophobia which can cause several negative effects, one of which is eye fatigue. Population that is vulnerable to the effects of smartphones is teenagers. The purpose of this study was to analyze the effect of mobile phone use and nomophobia on eye fatigue in students. The research population is student of STIKES Insan Unggul. The sample was selected using simple random sampling. The analysis is done using simple logistic regression and multiple logistic regressions. The data was collected using questionnaires. The results of the multivariable analysis showed that, the duration of mobile phone use (0.03; aPR 4.95), nomophobia (0.04; aPR 4.52), symptoms of using mobile phones before bed (0.03; aPR 12.5), using mobile phones $>30$ times a day $(0.03$; aPR 35.6). Preventive measures need to be taken to reduce and prevent the onset of nomphobia in students as well as causing advanced health problems.
\end{abstract}

Keywords $\quad$ : Eye Fatigue, Mobile Phone Use, Nomophobia

\begin{abstract}
ABSTRAK
Meningkatnya fitur dan fungsi smartphone menyebabkan timbulnya efek negatif seperti nomophobia serta beberapa efek negatif terusan salah satunya kelelahan mata. Populasi yang rentan efek dari smartphone adalah remaja dikarenakan penggunaan yang intens. Tujuan penelitian ini untuk menganalisis pengaruh penggunaan handphone dan nomophobia terhadap kelelahan mata pada mahasiswa. Populasi penelitian adalah mahasiswa STIKES Insan Unggul Surabaya. Sampel dipilih menggunakan simple random sampling dengan jumlah sampel sebanayk 64 orang. Analisis dilakukan menggunakan uji regresi logistik sederhana dan berganda. Data dikumpulkan menggunakan kuesioner dan lembar checklist. Hasil analisis multivariable yang dilakukan menunjukkan bahwa, durasi penggunaan handphone $(0,03$; aPR 4,95), nomophobia $(0,04$; aPR 4,52), gejala menggunakan handphone sebelum tidur $(0,03$; aPR 12,5$)$, menggunakan handphone $>30$ kali sehari $(0,03$; aPR 35,6) berhubungan dengan kejadian kelelahan mata pada responden. Perlu dilakukan tindakan preventif untuk mengurangi dan mencegah timbulnya nomophobia pada mahasiswa sebekum menimbulkan masalah kesehatan lanjutan.
\end{abstract}

Kata Kunci : Kelelahan Mata, Nomophobia, Pengguaan Handphone

\section{PENDAHULUAN}

Pada tahun 2014 ada 7,2 miliar pengguna handphone diseluruh dunia dan jumlahnya semakin meningkat. Pada kuartal pertama tahun 2015 tercatat ada 105juta pengguna smartphone baru dimana diperkirakan pada tahun 2016 jumlah pengguna smartphone diseluruh dunia akan melampaui jumlah penduduk dunia (B. Chen et al., 2017). Pertumbuhan pengguna smartphone yang cukup pesat dilatarbelakangi oleh berbagai faktor yang pertama adalah meningkatnya jumlah penduduk dunia baik dinegara maju seperti di
USA maupun dinegara berkembang seperti di India dan Indonesia (Statista, 2019). Faktor kedua adalah semakin meningkatnya fungsi dari smartphone yang memberikan banyak manfaat bagi kehidupan manusia mulai dari alat komunikasi, mobile gaming, online shopping, social media, dll (L. Chen et al., 2016; Thomée, Härenstam, \& Hagberg, 2014).

Meningkatnya fungsi dan manfaat smartphone terhadap kehidupan manusia laksana pedang bermata dua yaitu apabila dimanfaatkan dengan baik akan menghasilkan manfaat yang dapat dirasakan, namun apabila 
tidak dimanfaatkan dengan baik maka akan menghasilkan dampak negatif salah satunya adalah no mobile phone phobia (nomophobia) (Zheng, 2015). Nomophobia adalah rasa takut, gelisah, cemas dan stress yang di alami ketika berjauhan dari handphone atau kehilangan telephone (Latta, 2014). Nomophobia adalah masalah psikologis yang dialami oleh seseorang ketika seseorang mengalami kecanduan yang berlebihan terhadap smartphone. Nomophobia menjadi sebuah awal dari berbagai gangguan kesehatan yang dapat timbul mulai dari masalah ekonomi dan sosial seperti menurunnya produktifitas kerja maupun menurunnya interaksi sosial akibat meningkatnya penggunaan handphone (Cheever, Rosen, Carrier, \& Chavez, 2014; Clayton, Leshner, \& Almond, 2015). Selain itu, nomophobia juga akan berdampak pada kondisi fisik seperti timbulnya rasa sakit pada pundak dan leher, gangguan otak akibat paparan radiasi, namun masalah kesehatan fisik yang paling sering muncul adalah gangguan kelelahan mata (Demirci, Akgönül, \& Akpinar, 2015; Kwon et al., 2013). Mata adalah salah satu indera yang paling sering digunakan ketika seseorang mengakses / menggunakan smartphone, oleh karena itu mata adalah indera pertama yang akan mengalami masalah ketika seseorang mengalami nomophobia dengan tingkat penggunaan handphone yang tinggi (Farooqui, Pore, \& Gothankar, 2018).

Salah satu populasi rentan terkena nomophobia adalah remaja hal ini disebabkan karena remaja menjadikan smartphone tidak hanya sebagai alat untuk mempermudah hidup, tetapi juga menjadikan smartphone sebagai gaya hidup dan kebutuhan harian serta tumbuh berkembang dengan smartphone di jaman millennial dan era digital yang sedang berlangsung (Rather \& Rather, 2019). Dengan kondisi yang demikian maka perlu dilakukan demikian untuk mengidentifikasi seberapa banyak remaja khususnya mahasiswa yang mengalami nomophobia dan kelelahan mata sehingga dapat digunakan untuk pengambilan kebijakan untuk mencegah timbulnya masalah lain yang lebih besar.

\section{METODE}

Populasi penelitian ini adalah seluruh mahasiswa STIKES Insan Unggul Surabaya yang berada di kampus saat penelitian dan pengambilan data berlangsung. Sampel penelitian dipilih menggunakan Teknik Simple Random Sampling. Hasil perhitungan besar sampel didapatkan jumlah sampel sebanyak 64 orang. Sampel dipilih menggunakan kriteria inklusi berusia minimal 17 tahun, memiliki smartphone, telah menggunakan smartphone $>2$ tahun, memiliki akses internet, tidak sedang melaksanakan praktikum / magang, tidak memiliki kelainan visus, bersedia untuk menginstal aplikasi SmartphoneUseFree dan bersedia mengikuti proses pengumpulan data sampai akhir.

Penelitian dilakukan selama 3 bulan yaitu pada bulan Februari 2016 - April 2016. Pengumpulan data dilakukan menggunakan kuesioner dan lembar checklist. Pengumpulan data dilakukan melalui metode wawancara langsung. Selain itu pengumpulan data juga dilakukan dengan cara menginstal aplikasi SmartphoneUseFree yang bertujuan untuk mencatat data penggunaan handphone yang berkaitan dengan jumlah penggunaan harian, durasi penggunaan dan waktu penggunaan terbanyak responden. penginstalan aplikasi dilakukan dengan seijin responden

Data sosio demografi dikumpulkan menggunakan kuesioner yang dibuat oleh peneliti. Data dikumpulkan terkait sosio demografi mencakup usia, jenis kelamin, program studi.

Data aktifitas penggunaan handphone dikumpulkan melalui Aplikasi SmartphoneUseFree yang di instal kemudian dilakukan pengecekan data 3 minggu setelah penginstalan. Data yang dikumpulkan meliputi jumlah penggunaan handphone harian, durasi penggunaan dan waktu akese handphone favorit responden.

Data nomophobia dikumpulkan menggunakan lembar checklist yang berisi terkait dari gejala nomphobia menurut Latta, (2014) yaitu Tidak pernah mematikan 
handphone, Merasa cemas ketika mematikan handphone, Merasa gelisah atau sakit kepala ketika jauh dari handphone, Secara otomatis mengecek missed call, email, pesan singkat atau notifikasi lainnya, Selalu memastikan bahwa baterai handphone tidak berada di 'red zone', Selalu membawa handphone ke kamar mandi, Selalu menyempatkan waktu untuk mengecek handphone (>30kali sehari), Tidur bersama ponsel. Apabila responden mengalami $\geq 3$ gejala, maka responden tersebut dikatakan mengalami nomophobia.

Kelelahan mata dikumpulkan menggunakan lembar checklist yang berisi terkait gejala kelalahan mata menurut Ilyas, (2008) yaitu Iritasi pada mata atau konjungtivitas (konjungtiva berwarna merah dan mengelurkan air mata), Nyeri pada mata, Mata kering, Mata gatal, Mata berai, Penglihatan ganda (double vision), Sakit kepala, Daya akomodasi dan konvergensi menurun, Ketajaman penglihatan, kepekaan kontras dan kecepatan persepsi menurun.

Analisis data dilakukan 3 tahap yaitu analisis secara univariable, analisis secara bivariable dan analisis data secara multivariable. analisis data univariable dilakukan untuk menampilkan distribusi frekuensi dari setiap variabel yang ada. analisis variabel dilakukan dengan menggunakan uji regresi logistik sederhana yang mana uji bivariable juga dilakukan sebagai uji kandidat analisis multivariable, apabila signifikansi variable $<0,10$ maka merupakat kandidat untuk uji multivaribel. Uji multivariable dilakukan menggunakan analisis regresi logistik berganda. Analisis ini digunakan untuk melihat interaksi antar variabel.

\section{HASIL}

Analisis yang dilakukan menunjukkan bahwa sebagian besar responden yang mengalami kelelahan mata berusia $\leq 21$ tahun, hasil analisis yang telah dilakukan menunjukkan bahwa tidak ada hubungan antara usia responden dengan kejadian kelelahan mata $(\mathrm{p}=0,49)$. Jenis kelamin laki - laki pada responden memiliki angkat kejadian kelelahan mata yang lebih besar jika dibandingkan dengan jenis kelamin perempuan, hasil analisis yang dilakukan menunjukkan bahwa jenis kelamin tidak berhubungan dengan kejadian kelelahan mata pada responden $(\mathrm{p}=0,25)$. Pada variabel program studi, jumlah responden yang mengalami kelelahan mata nyaris berimbang namun mahasiswa program studi Kebidanan memiliki masalah kelelahan mata lebih banyak dibandingkan program studi lain dengan hasil analisis yang juga tidak signifikan antara program studi dengan kejadian kelelahan mata $(\mathrm{p}=0,33)$.

Tabel 1. Karakteristik Sosio Demografi Responden

\begin{tabular}{|c|c|c|c|c|c|}
\hline \multirow{2}{*}{\multicolumn{2}{|c|}{ Variabel }} & \multicolumn{2}{|c|}{$\begin{array}{l}\text { Kelelahan } \\
\text { Mata }\end{array}$} & \multirow[t]{2}{*}{ Sig } & \multirow[t]{2}{*}{ PR } \\
\hline & & Tidak & $\mathrm{Ya}$ & & \\
\hline \multirow[t]{2}{*}{ Usia } & $>21$ & 6 & 26 & \multirow{2}{*}{0,49} & \multirow{2}{*}{ - } \\
\hline & $<=21$ & 4 & 28 & & \\
\hline \multirow{2}{*}{$\begin{array}{l}\text { Jenis } \\
\text { Kelamin }\end{array}$} & Laki - Laki & 9 & 39 & \multirow{2}{*}{0,25} & \multirow{2}{*}{-} \\
\hline & Perempuan & 1 & 15 & & \\
\hline \multirow{4}{*}{$\begin{array}{l}\text { Program } \\
\text { Studi }\end{array}$} & Kesehatan & & & \multirow{4}{*}{0,33} & \multirow{4}{*}{-} \\
\hline & Masyarakat & 3 & 18 & & \\
\hline & Keperawatan & 1 & 17 & & \\
\hline & Kebidanan & 6 & 19 & & \\
\hline
\end{tabular}

Responden yang mengalami kelelahan mata sebagian besar menggunakan handphone $>50$ kali dalam sehari. Hasil analisis yang dilakukan menunjukkan bahwa jumlah penggunaan handphone harian berhubungan dengan kejadian kelelahan mata $(\mathrm{p}=0,03<\alpha 0,10)$ dengan PR sebesar 4,66. Hasil analisis menunjukkan bahwa sebagian besar responden menggunakan handphone $\leq 4$ jam sehari. Hasil analisis bivariat yang dilakukan menunjukkan bahwa durasi penggunaan handphone harian responden berhubungan dengan kejadian kelelahan mata pada responden $(\mathrm{p}=0,03<\alpha 0,10)$ dengan PR sebesar 1,74. Sebagian besar responden mengakses handphone dengan intensitas yang tinggi pada jam 18.01 - 24.00, hasil analisis bivariabel yang dilakukan terhadap jam akses tertinggi menunjukkan hasil yang tidak signifikan $(p=0,03>\alpha 0,10)$.

Tabel 2. Karakteristik Aktifitas Penggunaan Smartphone Responden 


\begin{tabular}{|c|c|c|c|c|c|}
\hline \multirow{2}{*}{\multicolumn{2}{|c|}{ Variabel }} & \multicolumn{2}{|c|}{$\begin{array}{c}\text { Kelelahan } \\
\text { Mata }\end{array}$} & \multirow[t]{2}{*}{ Sig } & \multirow[t]{2}{*}{ PR } \\
\hline & & Tidak & $\mathrm{Ya}$ & & \\
\hline \multirow{3}{*}{$\begin{array}{l}\text { Jumlah } \\
\text { Penggunaa } \\
\mathrm{n} \\
\text { Handphone } \\
\text { Harian }\end{array}$} & $>50$ & 3 & 36 & \multirow{3}{*}{$0,03 *$} & \multirow{3}{*}{4,66} \\
\hline & $<=50$ & & & & \\
\hline & & 7 & 18 & & \\
\hline \multirow{4}{*}{$\begin{array}{l}\text { Durasi } \\
\text { Penggunaa } \\
\mathrm{n} \\
\text { Handphone }\end{array}$} & $>4$ & & & \multirow{4}{*}{$0,04 *$} & \multirow{4}{*}{1.74} \\
\hline & Jam & 6 & 25 & & \\
\hline & $\leq=4$ & & & & \\
\hline & Jam & 4 & 29 & & \\
\hline \multirow{4}{*}{$\begin{array}{l}\text { Jam Akses } \\
\text { Tertinggi }\end{array}$} & $06.01-$ & & & \multirow{4}{*}{0,77} & \multirow{4}{*}{-} \\
\hline & 12.00 & 3 & 20 & & \\
\hline & $\begin{array}{l}12.01- \\
18.00\end{array}$ & 2 & 8 & & \\
\hline & $\begin{array}{l}18.01- \\
24.00\end{array}$ & 5 & 26 & & \\
\hline
\end{tabular}

*Signifikan pada $\alpha 10 \%$

Hasil analisis yang dilakukan menunjukkan bahwa sebagian besar responden mengalami nomophobia. Hasil analisis yang dilakukan menunjukkan bahwa nomphobia yang dialami responden berhubungan dengan kejadian kelelahan mata $(\mathrm{p}=0,01<\alpha 0,10)$ dengan PR sebesar 13,4. Gejala Nomophobia yang paling sering dialami oleh responden yaitu merasa cemas dan gelisah ketika jauh dari handphone, selalu memastikan bahwa baterai handphone tidak dalam keadaan lowbat, langsung mengecek handphone ketika ada notifikasi, menggunakan handphone sampai tertidur dan menggunakan handphone $>30$ kali sehari.

Tabel 3. Karakteristik Gejala Nomophobia Responden

\begin{tabular}{|c|c|c|c|c|c|}
\hline \multicolumn{2}{|c|}{ Variabel } & \multicolumn{2}{|c|}{$\begin{array}{l}\text { Kelelahan } \\
\text { Mata }\end{array}$} & \multirow[t]{2}{*}{ Sig } & \multirow[t]{2}{*}{ PR } \\
\hline & & Tidak & $\mathrm{Ya}$ & & \\
\hline \multirow[t]{2}{*}{ Nomophobia } & $\mathrm{Ya}$ & 7 & 8 & \multirow{2}{*}{$0,01 *$} & \multirow{2}{*}{13.4} \\
\hline & Tidak & 3 & 46 & & \\
\hline \multicolumn{6}{|l|}{$\begin{array}{l}\text { Gejala } \\
\text { Nomophobia }\end{array}$} \\
\hline Tidak Pernah & $\mathrm{Ya}$ & 4 & 25 & \multirow[b]{2}{*}{0,71} & \multirow[b]{2}{*}{ - } \\
\hline $\begin{array}{l}\text { Mematikan } \\
\text { Handphone }\end{array}$ & Tidak & 6 & 29 & & \\
\hline Merasa & $\mathrm{Ya}$ & 7 & 48 & \multirow{3}{*}{0,13} & \multirow{3}{*}{-} \\
\hline $\begin{array}{l}\text { Cemas dan } \\
\text { Gelisah } \\
\text { Ketika Jauh } \\
\text { Dari }\end{array}$ & & & & & \\
\hline Handphone & Tidak & 3 & 6 & & \\
\hline Merasa & $\mathrm{Ya}$ & 4 & 22 & 0,96 & - \\
\hline
\end{tabular}

\begin{tabular}{|c|c|c|c|c|c|}
\hline $\begin{array}{l}\text { Pusing Ketika } \\
\text { Jauh Dari } \\
\text { Handphone }\end{array}$ & Tidak & 6 & 32 & & \\
\hline Selalu & $\mathrm{Ya}$ & 5 & 40 & \multirow[b]{2}{*}{0,13} & \multirow[b]{2}{*}{-} \\
\hline $\begin{array}{l}\text { Mengecek } \\
\text { Baterai } \\
\text { Handphone }\end{array}$ & Tidak & 5 & 14 & & \\
\hline Selalu & $\mathrm{Ya}$ & 4 & 28 & \multirow[b]{2}{*}{0,49} & \multirow[b]{2}{*}{-} \\
\hline $\begin{array}{l}\text { Membawa } \\
\text { Charger / } \\
\text { Powerbank }\end{array}$ & Tidak & 6 & 26 & & \\
\hline Langsung & $\mathrm{Ya}$ & 6 & 36 & \multirow[b]{2}{*}{0,64} & \multirow[b]{2}{*}{-} \\
\hline $\begin{array}{l}\text { Mengecek } \\
\text { Handphone } \\
\text { Ketika Ada } \\
\text { Notifikasi }\end{array}$ & Tidak & 4 & 18 & & \\
\hline Membawa & $\mathrm{Ya}$ & 3 & 17 & \multirow[b]{2}{*}{0,96} & \multirow[b]{2}{*}{-} \\
\hline $\begin{array}{l}\text { Handphone } \\
\text { Kekamar } \\
\text { Mandi/Toilet }\end{array}$ & Tidak & 7 & 37 & & \\
\hline Menggunakan & $\mathrm{Ya}$ & 6 & 51 & & \\
\hline $\begin{array}{l}\text { Handphone } \\
\text { Sampai } \\
\text { Tertidur }\end{array}$ & Tidak & 4 & 3 & $0,00 *$ & 11,3 \\
\hline Tidur & $\mathrm{Ya}$ & 5 & 28 & \multirow[b]{2}{*}{0,91} & \multirow[b]{2}{*}{-} \\
\hline $\begin{array}{l}\text { Bersama } \\
\text { Handphone }\end{array}$ & Tidak & 5 & 26 & & \\
\hline Penggunaan & $\mathrm{Ya}$ & 5 & 53 & \multirow[b]{2}{*}{$0,00^{*}$} & \multirow[b]{2}{*}{53,0} \\
\hline $\begin{array}{l}\text { Handphone } \\
\text { Harian }>30 \\
\text { Kali }\end{array}$ & Tidak & 5 & 1 & & \\
\hline
\end{tabular}

*Signifikan pada $\alpha 10 \%$

Hasil analisis bivariat yang telah dilakukan menunjukkan bahwa terdapat 5 variabel yang menjadi kandidat uji multivariat yaitu Nomophobia, durasi penggunana handphone, gejala jumlah penggunaan handphone harian $>30$ kali sehari, gejala menggunakan handphone sampai tertidur dan gejala penggunaan. Hasil uji multivariat yang dilakukan menunjukkan bahwa Nomophobia, durasi pengguaan handphone, menggunakan handphone sampai tertidur dan penggunaan handphone harian >30 kali sehari secara simultan berhubungan dengan kejadian kelelahan mata pada responden. kejadian kelelahan mata pada responden 55,9 \% dipengaruhi oleh ke 4 variabel tersebut sedangkan sisanya dipengaruhi oleh faktor lain. 
Tabel 4. Hasil Uji Analisis Multivariat

\begin{tabular}{lcccc}
\hline \multirow{2}{*}{ Variabel } & \multirow{2}{*}{ Sig } & \multirow{2}{*}{ aPR } & \multicolumn{2}{c}{ CI } \\
\cline { 5 - 6 } & & & Lower & Upper \\
\hline Nomophobia & $0,04 *$ & 4,52 & 1,46 & 46,9 \\
\hline Durasi Penggunaan & $0,03 *$ & 4,95 & 1,44 & 43,8 \\
\hline $\begin{array}{l}\text { Gejala*Menggunakan } \\
\begin{array}{l}\text { Handphone Sampai } \\
\text { Tertidur }\end{array}\end{array}$ & $0,03 *$ & 12,5 & 1,196 & 13,1 \\
\hline $\begin{array}{l}\text { Gejala*Penggunaan } \\
\text { Handphone Harian } \\
\text { >30 Kali }\end{array}$ & $0,03 *$ & 35,6 & 1,255 & 11,3 \\
\hline *Signifikan pada $\alpha 5 \%, R^{2}$ & 0,559 & & & \\
\hline
\end{tabular}

Hasil uji multivariat yang dilakukan menunjukkan bahwa Nomphobia, durasi pengguaan handphone, menggunakan handphone sampai tertidur dan penggunaan handphone harian >30 kali sehari secara simultan berhubungan dengan kejadian kelelahan mata pada responden. kejadian kelelahan mata pada responden 55,9 \% dipengaruhi oleh ke 4 variabel tersebut sedangkan sisanya dipengaruhi oleh faktor lain.

\section{Tabel 5. Karakteristik Gejala Kelelahan Mata} Responden

Gejala Kelelahan Mata

\begin{tabular}{lll}
\hline Iritasi / Konjngtiva & Ya & 11 \\
\cline { 2 - 3 } & Tidak & 53 \\
\hline \multirow{2}{*}{ Nyeri Pada Mata } & Ya & 11 \\
\cline { 2 - 3 } & Tidak & 53 \\
\hline \multirow{2}{*}{ Mata Kering } & Ya & 25 \\
\cline { 2 - 3 } & Tidak & 39 \\
\hline Mata Gatal & Ya & 14 \\
\cline { 2 - 3 } & Tidak & 50 \\
\hline Mata Berair & Ya & 20 \\
\cline { 2 - 3 } & Tidak & 44 \\
\hline Double Vision / Berbayang & Ya & 1 \\
\cline { 2 - 3 } & Tidak & 63 \\
\hline Sakit Kepala & Ya & 22 \\
\cline { 2 - 3 } & Tidak & 42 \\
\hline Akomodasi dan Konvergensi & Ya & 2 \\
\cline { 2 - 3 } Menurun & Tidak & 62 \\
\hline Ketajaman Penglihatan & Ya & 6 \\
\cline { 2 - 3 } Menurun & Tidak & 58 \\
\hline
\end{tabular}

Kondisi Kelelahan mata terjadi pada sebagian besar responden. gejala yang paling sering dialami oleh responden adalah mata kering, mata berair, sakit kepala. Sedangkan gejala kelelahan mata yang jarang dialami oleh responden adalah akomodasi dan konvergensi menurun, double vision dan ketajaman penglihatan menurun.

\section{PEMBAHASAN}

Hasil penelitian yang dilakukan mendapatkan hasil bahwa usia responden secara statistik tidak berhubungan dengan kejadian kelelahan mata. Sebagian besar responden memiliki usia $<21$ tahun. Selain itu jenis kelamin juga tidak memiliki hasil analisis yang signifikan dengan kejadian kelelahan mata responden. Hasil penelitian yang dilakukan oleh Dongre, Inamdar and Gattani, (2017) menyebutkan bahwa usia dan jenis kelamit tidak berhubungan dengan kejadian kelelahan mata dan dampak lain yang timbul berkenaan kejadian nomophobia. Meskipun terjadi peningkatan yang signifikan terhadap pengguna usia remaja namun kondisi kesehatan remaja yang belum rentan untuk terkena berbagai masalah kesehatan menyebabkan usia remaja memiliki tingkat kelelahan mata yang cukup rendah. Selain itu masih tingginya aktifitas diluar ruangan pada remaja menyebabkan remaja memiliki perlindungan berupa waktu istirahat dari penggunaan handphone yang cukup baik sehingga memiliki tingkat kelelahan mata yang lebih baik (Praveen Ganganahalli, 2014; Sadagopan et al., 2017)

Hasil penelitian aktifitas penggunaan handphone dengan kelelahan mata menunjukkan hasil analisis yaitu durasi penggunaan handphone harian dan jumlah penggunaan handphone harian menunjukkan hasil yang signifikan terhadap kelelahan mata yang dialami oleh responden. Semakin tinggi tinkat durasi penggunaan handphone harian dan semakin tinggi jumlah penggunaan handphone harian menyebabkan kejadian tingkat kelelahan mata juga semakin meningkat. Penelitian ini juga sejalan dengan penelitain yang dilakukan oleh Rather and Rather, (2019) dimana semakin meningkat durasi dan jumlah penggunaan handphone harian akan meningkatkan dampak masalah kesehatan yang timbul mulai dari kelelahan mata, sakit leher dan punggung juga sakit kepala. Hasil penelitian serupa juga 
ditemukan pada penelitian yang dilakukan pada Alabdulkader, (2021) menyebutkan bahwa semakin tinggi durasi penggunaan handphone maka akan menyebabkan timbulnya masalah kelelahan mata pada responden. Layar handphone merupakan salah satu sumber radiasi cahaya biru (Blue light) yang dapat menyebabkan kelelahan pada mata khususnya pada kornea dan retina mata, paparan yang tinggi dengan waktu yang lama dari cahaya biru dapat menyebabkan timbulnya masalah kesehatan mata salah satunya kelelahan mata. Selain itu fokus mata dalam waktu lama terhadap objek kecil di handphone juga menjadi salah satu penyebab timbulnya kelelahan mata pada responden (Ganne, Najeeb, Chaitanya, Sharma, \& Krishnappa, 2021; Mylona, Deres, Dere, Tsinopoulos, \& Glynatsis, 2020).

Hasil analisis yang dilakukan menunjukkan bahwa nomophobia berhubungan dengan kejadian kelelahan mata pada responden. Mahasiswa yang menderita Nomophobia menggunakan handphone dalam jangka waktu yang lama. Hasil penelitian serupa ditemukan pada penelitian yang dilakukan oleh Ghogare et al., (2021) menyatakan bahwa terdapat pengaruh antara nomophobia dengan timbulnya kelelahan mata pada responden. hasil penelitian serupa juga ditemukan pada penelitian yang dilakukan oleh Boyer, (2021) menyatakan bahwa penggunaan handphone yang berlebihan dapat menyebabkan timbulnya kelelahan mata pada remaja. Penggunaan yang berlebihan menyebabkan kelelahan mata dengan gejala awal yang timbul adalah mata kering, hal ini karena ketika mata mahasiswa menatap layar handphone dengan fokus maka intensitas dia berkedip akan menurun, sehingga mahasiswa yang menderita gejala ini mencapai 26 responden. Selain itu penyebab lainnya adalah blue light atau sinar biru yang dipancarkan oleh layar handphone. Sinar biru apabila terlalu sering masuk ke dalam mata akan menyebabkan stress pada retina, hal ini karena sinar biru merupakan sinar yang sanggup mencapai belakang mata yaitu pada bagian retina sehingga menyebabkan kelelahan pada retina (Sarla 2020).

Menurut Siswanto, (2007), kelelahan mata merupakan akibat dari stress pada alat penglihatan. Kelelahan mata disebabkan oleh stress yang intensif pada fungsi tunggal (single funcion) dari mata. Stress yang persisten pada otot akomodasi (Ciliary Muscle) dapat terjadi pada saat seseorang menyalakan inspeksi pada obyek-obyek yang berukuran kecil dan pada jarak dekat serta dalam waktu lama, dan stress pada retina dapat terjadi bila terdapat kontras yang berlebihan dalam lapang penglihatan dan waktu pengamatan yang cukup lama. Mata kering sering di alami oleh mahasiswa yang menderita nomophobia hal ini disebabkan kondisi ketika seseorang memainkan handphone maka dia akan menatap fokus terhadap obyek kecil dalam waktu yang lama sehingga intensitas berkedip yang merupakan proses pelumasan mata menjadi berkurang setengahnya sehingga mata menjadi kering. Selain itu cahaya terang dari handphone juga mempengaruhi terjadinya mata kering pada mahasiswa.

Mata yang berakomodasi terus menerus dalam waktu yang lama akan menurunkan kemampuan penglihatan dekatnya dan menyebabkan nyeri kepala dan nyeri pada mata. Stress pada retina dapat terjadi bila terdapat "kontras" yang berlebihan dalam lapang penglihatan (visual field) dan waktu pengamatannya yang cukup lama (Imansyah, 2011). Gejala ini disebabkan oleh efek stres yang di rasakan otot serta saraf di mata sehingga menyebabkan kepala pusing ketika menatap layar handphone terlalu lama. Selain itu efek radiasi dari handphone juga menyebabkan efek pusing bagi yang memiliki hypersensitif terhadap radiasi. Mencegah ketegangan mata akan mengurangi peluang kehilangan penglihatan untuk menghindari ketegangan, mata sebaiknya beristirahat dengan menfokuskan pada obyek lain beberapa menit (Iswidharmanjaya, 2014).

Mata sebaiknya dibiarkan basah dengan cara mengkedip, karena pada saat berkedip air mata akan diratakan keseluruh permukaan dan dialirkan keseluruh mata. Air mata dapat 
memperbaiki tajam penglihatan sesaat setelah berkedip. Gejala ini merupakan gejala lanjutan dari gejala mata kering. Mata berair timbul akibat rasa lelah akibat menatap layar handphone secara terus menerus sehingga menyebabkan mata kering dan kemudian akan berair akibat reflek natural mata untuk menghindari mata kering yang dapat menyebabkan efek lanjutan (Siswanto, 2017).

Mata yang berakomodasi terus menerus dalam waktu yang lama akan menurunkan kemampuan penglihatan dekatnya dan menyebabkan nyeri kepala dan nyeri pada mata. Stress pada retina dapat terjadi bila terdapat "kontras" yang berlebihan dalam lapang penglihatan (visual field) dan waktu pengamatannya yang cukup lama. Penyebab gejala ini mirip dengan mata berair di atas, gejala ini timbul akibat rasa kelelahan yang timbul akibat menatap layar handphone terus menerus mata akan kurang berkedip sehingga menyebabkan mata tidak nyaman dan gatal (Imansyah, 2011).

\section{KESIMPULAN}

Hasil penelitian yang telah dilakukan menunjukkan mahasiswa merupakan salah satu populasi yang rentan terkena kelelahan mata sebagai efek dari kondisi nomophobia dengan tingkat penggunaan handphone yang sangat tinggi. Timbulnya kelelahan mata pada mahasiswa disebabkan oleh durasi penggunaan handphone, kondisi nomophobia yang dimiliki, serta gejala nomophobia yaitu penggunaan handphone $>30$ kali dalam sehari serta memainkan handphone saat malam hari sampai tertidur. Perlu dilakukan tindakan pencegahan untuk mencegah timbulnya kelelahan mata dan untuk mencegah dampak yang lebih buruk dari kelelahan mata pada responden akibat overuse dari handphone akibat kondisi nomophobia mahasiswa. Apabila kondisi nomophobia sudah berkurang maka otomatis juga mengurangi overuse handphone sehingga diharapkan dampak yang terjadi juga berkurang dan bahkan hilang.

\section{UCAPAN TERIMAKASIH}

Peneliti mengucapkan terimakasih kepada seluruh civitas akademika STIKES Insan Unggul Surabaya yang telah membantu peneliti dalam menyelesaikan proses penelitian.

\section{DAFTAR PUSTAKA}

Alabdulkader, B. (2021). Effect of digital device use during COVID-19 on digital eye strain. Clinical and Experimental Optometry, 104(6), 698-704. https://doi.org/10.1080/08164622.2021. 1878843

Boyer, A. S. (2021). Independent Schools Association of the Central States Accredited Private School Professional Teachers' Levels of Nomophobia. Baker University.

Cheever, N. A., Rosen, L. D., Carrier, L. M., \& Chavez, A. (2014). Computers in Human Behavior Out of sight is not out of mind: The impact of restricting wireless mobile device use on anxiety levels among low, moderate and high users. Computers In Human Behavior, 37 , 290-297. https://doi.org/10.1016/j.chb.2014.05.0 02

Chen, B., Liu, F., Ding, S., Ying, X., Wang, L., \& Wen, Y. (2017). Gender differences in factors associated with smartphone addiction: A crosssectional study among medical college students. BMC Psychiatry, 17(1), 1-9. https://doi.org/10.1186/s12888-0171503-z

Chen, L., Yan, Z., Tang, W., Yang, F., Xie, X., \& He, J. (2016). Mobile phone addition levels and negative emotions among Chinese young adults: The mediating role of interpersonal problems. Computers in Human Behavior, 55, 856-866. https://doi.org/10.1016/j.chb.2015.10.0 30

Clayton, R. B., Leshner, G., \& Almond, A. (2015). The Extended iSelf: The 
Impact of iPhone Separation on Cognition, Emotion, and Physiology. $1-17$. https://doi.org/10.1111/jcc4.12109

Demirci, K., Akgönül, M., \& Akpinar, A. (2015). Relationship of smartphone use severity with sleep quality, depression, and anxiety in university students. Journal of Behavioral Addictions, 4(2), 85-92.

https://doi.org/10.1556/2006.4.2015.01 0

Dongre, A., Inamdar, I., \& Gattani, P. (2017). Nomophobia: A Study to Evaluate Mobile Phone Dependence and Impact of Cell Phone on Health. National Journal of Community Medicine, 8(11), 688-693. Retrieved from www.njcmindia.org

Farooqui, I. A., Pore, P., \& Gothankar, J. (2018). Nomophobia: an emerging issue in medical institutions? Journal of Mental Health, 27(5), 438-441. https://doi.org/10.1080/09638237.2017. 1417564

Ganne, P., Najeeb, S., Chaitanya, G., Sharma, A., \& Krishnappa, N. C. (2021). Digital Eye Strain Epidemic amid COVID-19 Pandemic-A Cross-sectional Survey. Ophthalmic Epidemiology, 28(4), 285292.

https://doi.org/10.1080/09286586.2020. 1862243

Ghogare, A., Aloney, S., Vankar, G., Bele, A., Patil, P., \& Ambad, R. (2021). A cross-sectional online survey of an impact of COVID-19 lockdown on smartphone addiction and nomophobia among undergraduate health sciences students of a rural tertiary health-care center from Maharashtra, India. Annals of Indian Psychiatry, $O(0), 0$. https://doi.org/10.4103/aip.aip_38_21

Ilyas, S. (2018). Penuntun Ilmu Penyakit Mata. Jakarta: Pustaka Utama Grafiti.

Imansyah, A. (2011). Dampak Kelelahan Mata Terhadap Produktifitas Kerja. Jakarta: Rineka Cipta.

Iswidharmanjaya, D. (2014). Bila Si Kecil Bermain gadget. Jakarta: Beranda
Agency.

Kwon, M., Lee, J., Won, W., Park, J., Min, J., Hahn, C., ... Kim, D. (2013). Development and Validation of a Smartphone Addiction Scale ( SAS ). $8(2)$.

https://doi.org/10.1371/journal.pone.00 56936

Latta, S. (2014). Scared Stiff: Everything You Need to Know about 50 Famous Phobias. Houghton: Houghton Mifflin Harcourt.

Mylona, I., Deres, E. S., Dere, G. D. S., Tsinopoulos, I., \& Glynatsis, M. (2020). The Impact of Internet and Videogaming Addiction on Adolescent Vision: A Review of the Literature. Frontiers in Public Health, 8(March), 1-6.

https://doi.org/10.3389/fpubh.2020.000 63

Praveen Ganganahalli, M. (2014). Use of Electronic Gadgets among Medical Students in Western Maharashtra, India. -. International Journal of Health Sciences and Research (IJHSR), 4(9), 26-30.

Rather, M. K., \& Rather, S. A. (2019). Impact of smartphones on young generation. Library Philosophy and Practice, 2019.

Sadagopan, A. P., Manivel, R., Marimuthu, A., Nagaraj, H., Ratnam, K., Taherakumar, ... Jeyaraj, G. (2017). Prevalence of Smart Phone Users at Risk for Developing Cell Phone Vision Syndrome among College Students. Journal of Psychology \& Psychotherapy, 07(03), 1-4. https://doi.org/10.4172/21610487.1000299

Sarla, G. S. (2020). Excessive use of electronic gadgets: health effects. The Egyptian Journal of Internal Medicine, 31(4), 408-411. https://doi.org/10.4103/ejim.ejim_56_1 9

Siswanto, S. (2017). Manajemen Tenaga Kerja Indonesia. Jakarta: Bumi Aksara. 
Statista. (2019). Number of smartphone users worldwide 2014-2020. Retrieved October 18, 2019, from https://www.statista.com/statistics/3306 95/number-of-smartphone-usersworldwide/

Thomée, S., Härenstam, A., \& Hagberg, M. (2014). Mobile phone use and stress, sleep disturbances, and symptoms of depression among young adults - a prospective cohort study. BMC Public Health. https://doi.org/10.1186/14712458-11-66

Zheng, Y. (2015). Encyclopedia of Mobile Phone Behavior. Harshey: IGI Global. 